\title{
Active immunization of cattle against partly purified follicular fluid from sheep*
}

\author{
C. A. Price†, B. A. Morrisł, T. O’Shea§ and R. Webb
}

Department of Reproduction and Growth Physiology, A.F.R.C. Institute of Animal Physiology and Genetics Research, Edinburgh Research Station, Roslin, Midlothian EH25 9PS, U.K., $\ddagger$ Department of Biochemistry, University of Surrey, Guildford, Surrey GU2 $5 X H, U . K$. and $\S$ Department of Physiology, University of New England, Armidale, New South Wales 2351, Australia

\begin{abstract}
Summary. Yearling cross-bred heifers were injected with 0.4 or $4 \mathrm{mg}$ total protein in non-ulcerative Freund's adjuvant (Groups $A$ and $C$, respectively; $N=5$ per group), or adjuvant with $C$. parvum (Groups $\mathrm{B}$ and $\mathrm{D}$, respectively; $\mathrm{N}=5$ per group). Control heifers were not treated $(\mathrm{N}=9)$. No antibodies were detected in heifers in Groups $\mathrm{A}$ and $\mathrm{C}$ and so these were excluded from the analysis. There was no effect of the treatment on Group B or D heifers after the priming or first booster injection. After a second booster injection one Group D heifer gave a triple ovulation, and two Group D heifers and one Group B heifer gave double ovulations, but for one oestrous cycle only. Group B heifers also showed a significant rise in FSH concentrations after the second booster injection. Group D heifers were given a third booster injection; there was an increase in the mean number of large follicles per heifer, and a decrease in oestrous cycle length, but no increase in ovulation rate.

These results indicate that a transient increase in ovulation rate can be induced by actively immunizing cattle against partly purified follicular fluid from sheep.
\end{abstract}

\section{Introduction}

The prolificacy of sheep, i.e. the number of young born per parturition, can be increased in a number of ways. These include genetic selection (Bradford, 1985) and active (Scaramuzzi \& Hoskinson, 1984) and passive (Webb et al., 1984) immunization against gonadal steroids. These techniques can be used to ensure a high incidence of twin and triplet births. The same principles, however, cannot be applied reliably to the cow: the frequency and heritability of twinning in cattle are both very low (Rutledge, 1975; Maijala \& Syvajarvi, 1977) and immunization against gonadal steroids has been shown to produce variable results (Martin et al., 1978; Wise \& Schanbacher, 1983; Price et al., 1987) with similar antibody titres inducing not only multiple ovulations but also anoestrus.

A gonadal protein(s) which may be a negative feedback agent, inhibin, has been shown to suppress selectively the secretion of follicle-stimulating hormone (FSH) in the rat (Welschen et al., 1977), sheep (McNeilly, 1984) and cow (Ireland et al., 1983) and decrease ovarian activity in hamsters (Chappel \& Selkar, 1979), sheep and cattle (Miller et al., 1979; Quirk \& Fortune, 1986). Active immunization of sheep against partly purified bovine follicular fluid (a source of inhibin) increased the incidence of multiple ovulations (Henderson et al., 1984; Cummins et al., 1986) and of twin and

*Reprint requests to $\mathrm{R}$. Webb.

†Present address: Wallaceville Animal Research Centre, Research Division, Ministry of Agriculture and Fisheries, Private Bag, Upper Hutt, New Zealand. 
triplet fetuses during early pregnancy (O'Shea et al., 1984). The objective of this study was to increase the incidence of twin ovulations in heifers by actively immunizing against partly purified ovine follicular fluid.

\section{Materials and Methods}

Animals. Charolais and Simmental cross yearling heifers were studied for 16 months on the Institute farms in Scotland. The 29 heifers were housed indoors during the winter months and fed hay and standard concentrate, with fresh water available ad libitum. All animals gained weight during the trial.

Antigen. The inhibin-enriched fraction of ovine follicular fluid was prepared by the method of Jansen et al. (1981) from washed slaughterhouse material. Briefly, follicular fluid was aspirated from follicles $>3 \mathrm{~mm}$ in diameter (excluding obviously cystic structures), centrifuged to remove cell debris, charcoal-treated to remove most of the steroids present ( $1 \mathrm{mg}$ charcoal $/ \mathrm{ml}$ and $0.1 \mathrm{mg}$ dextran $\mathrm{T}-70 / \mathrm{ml}$ for $30 \mathrm{~min}$ at $4^{\circ} \mathrm{C}$ ), and subjected to affinity chromatography on Matrix gel Red A. Elutions from several columns were pooled to form a single batch of antigen, with a protein concentration of $2.7 \mathrm{mg} / \mathrm{ml}$. The biological activity of the antigen was examined using a mouse ovulation rate model based on that of Cummins (1983) with modifications. Mature outbred female mice (Bantin and Kingman, Hull, U.K.) weighing $20-25 \mathrm{~g}$ were taken at random and given an intraperitoneal injection of $0.1 \mathrm{ml} 0.9 \%$ sterile saline (Travenol Laboratories Ltd, Thetford, Norfolk, U.K.) containing 0-500 $\mathrm{g}$ of antigen at 09:00 h, followed by an intraperitoneal injection of 10 i.u. hCG (Chorulon; Intervet, Cambridge, U.K.) in 0.1 ml sterile saline at 17:00 h on the same day. The mice were killed the following morning, and the ova were removed from the oviduct and counted.

Protocol. The animals were divided into 4 treatment groups of 5 heifers, and a control group of 9 heifers. The treatment animals were immunized against two dose levels of antigen $(0.4 \mathrm{mg}$ or $4 \mathrm{mg}$ protein per animal) in nonulcerative Freund's adjuvant (Guildhay Antisera, University of Surrey, Guildford), with or without Corynebacterium parvum (Wellcome Biotechnology, Beckenham, Kent). The composition of the emulsions for each group is given in Table 1. The emulsion was injected intramuscularly, a quarter of the total volume into each of the four legs. Additionally, all treatment animals received a single $2.5 \mathrm{ml}$ injection of Bordetella pertussis (Wellcome Foundation Ltd, Dartford, Kent) subcutaneously in the brisket. The control heifers were not injected. After the priming injection, animals immunized without $C$. parvum were given 2 booster injections, and animals immunized with $C$. parvum were given 3 booster injections at 4 -month intervals. The first booster was identical to the priming injection, whereas the second and third booster injections were devoid of $C$. parvum and B. pertussis. Before the 3rd booster injection, the number of control heifers was reduced to 6 , and one animal from Group B was slaughtered because of illness unrelated to the experimental procedures.

Table 1. Composition of the emulsion for each animal in each of the treatment groups

\begin{tabular}{llccc}
\hline & $\begin{array}{c}\text { Antigen } \\
(\mathrm{mg} ; \mathrm{ml})\end{array}$ & $\begin{array}{c}\text { NUFA* } \\
(\mathrm{ml})\end{array}$ & $\begin{array}{c}\text { Water } \\
(\mathrm{ml})\end{array}$ & $\begin{array}{c}\text { C. parvum } \\
(\mathrm{ml})\end{array}$ \\
\hline Group A & $0.4 ; 0.16$ & 1.5 & 1.5 & - \\
Group B & $0.4 ; 0.16$ & 1.5 & 0.5 & 1.0 \\
Group C & $4.0 ; 1.6$ & 1.5 & - & - \\
Group D & $4.0 ; 1.6$ & 1.5 & - & $1.0 \dagger$ \\
\hline
\end{tabular}

*Non-ulcerative Freund's adjuvant.

†Freeze-dried and dissolved in the antigen preparation before emulsification.

Observations for oestrus were made at least twice daily aided by an oestrus-detection device (Kamar Inc., Steamboat Springs, Colorado, U.S.A.). Ovulation rate was determined by counting fresh corpora lutea on the ovaries between Days 7 and 14 after oestrus at mid-ventral laparoscopy under general anaesthesia; the presence of large follicles ( $>10 \mathrm{~mm}$ diameter) was also noted at laparoscopy. Ovulation rates were not determined for animals showing oestrus within 10 days of the second booster injection.

Jugular blood samples were taken weekly after the priming and first booster immunizations for antibody titre estimations, and 3 times weekly after the 2 nd and 3 rd booster injections to allow for assay of progesterone, and basal LH and FSH concentrations.

Antibody characterization. Antibody production was monitored by double diffusion in agar gels (Ouchterlony \& Nilsson, 1978); all gels were stained with Amido Black before being examined. The highest dilution of the antiserum which produced a line of precipitation was defined as the titre; the minimum detectable titre was set at one (neat 
antiserum). Cross-reactivity of the antisera against follicular fluids from the cow, pig, horse and human was tested in a similar double diffusion assay. The antisera were also tested for cross-reactivity against bovine and ovine whole serum, bovine serum albumin (BSA, Sigma), ovine LH (NIH-S18, FSH (NIH-S9), TSH (NIAMD-S9), and bovine prolactin (USDA-B1) and growth hormone (USDA-B1).

Hormone assays. LH and FSH were measured by the double antibody radioimmunoassays (RIA) described by Price $e t$ al. (1987), and were measured in a single assay for the periods after the 2 nd and 3rd hooster immunizations. The intra-assay coefficients of variation for both assays were below $4.0 \%$. The sensitivities of these assays were $0.4 \mathrm{ng}$ $\mathrm{LH} / \mathrm{ml}$ and $5.2 \mathrm{ng} \mathrm{FSH} / \mathrm{ml}$. Progesterone was measured by radioimmunoassay (Webb, 1987), with an extraction efficiency of $\sim 70 \%$; the sensitivity of the assay was $0.12 \mathrm{ng} / \mathrm{ml}$. The inter- and intra-assay coefficients of variation over 4 assays were 18.9 and $17.1 \%$, and 22.9 and $14.2 \%$, respectively for pooled serum samples containing 1.5 and $3.0 \mathrm{ng} / \mathrm{ml}$.

Statistics. Hormone data are expressed as geometric means ( \pm s.e.m.), whereas other data are given as arithmetic means. Differences between means were tested by Student's $t$ test, except for large follicle populations which were analysed by the Mann-Whitney rank test.

\section{Results}

\section{Antigen}

The antigen was biologically active in the mouse ovulation rate model used (Fig. 1).

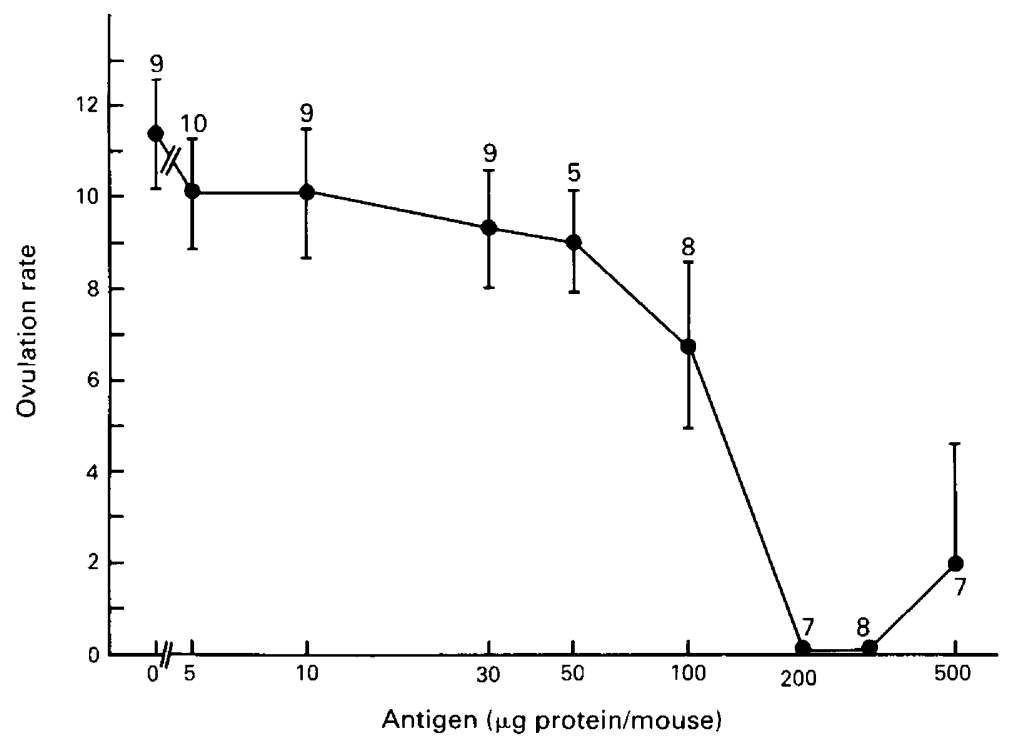

Fig. 1. Dose-response curve of the effect of the inhibin-enriched follicular fluid preparation on ovulation rate in the mouse. Numbers above each point represent the number of mice at each dose.

\section{Immunological response}

All heifers immunized with C. parvum (Groups B \& D) showed an immune response (Fig. 2) whereas those without $C$. parvum (Groups A \& C) did not produce any detectable antibodies (data not shown). The antibody titres attained by the $0.4 \mathrm{mg}$ dose group (Group B) following peak titre levels were significantly lower than those of the $4.0 \mathrm{mg}$ group (Group D) after all booster injections $(P<0.05)$. Some animals of both groups displayed local hypersensitivity reactions at the injection sites, but these regressed without abscess formation. 


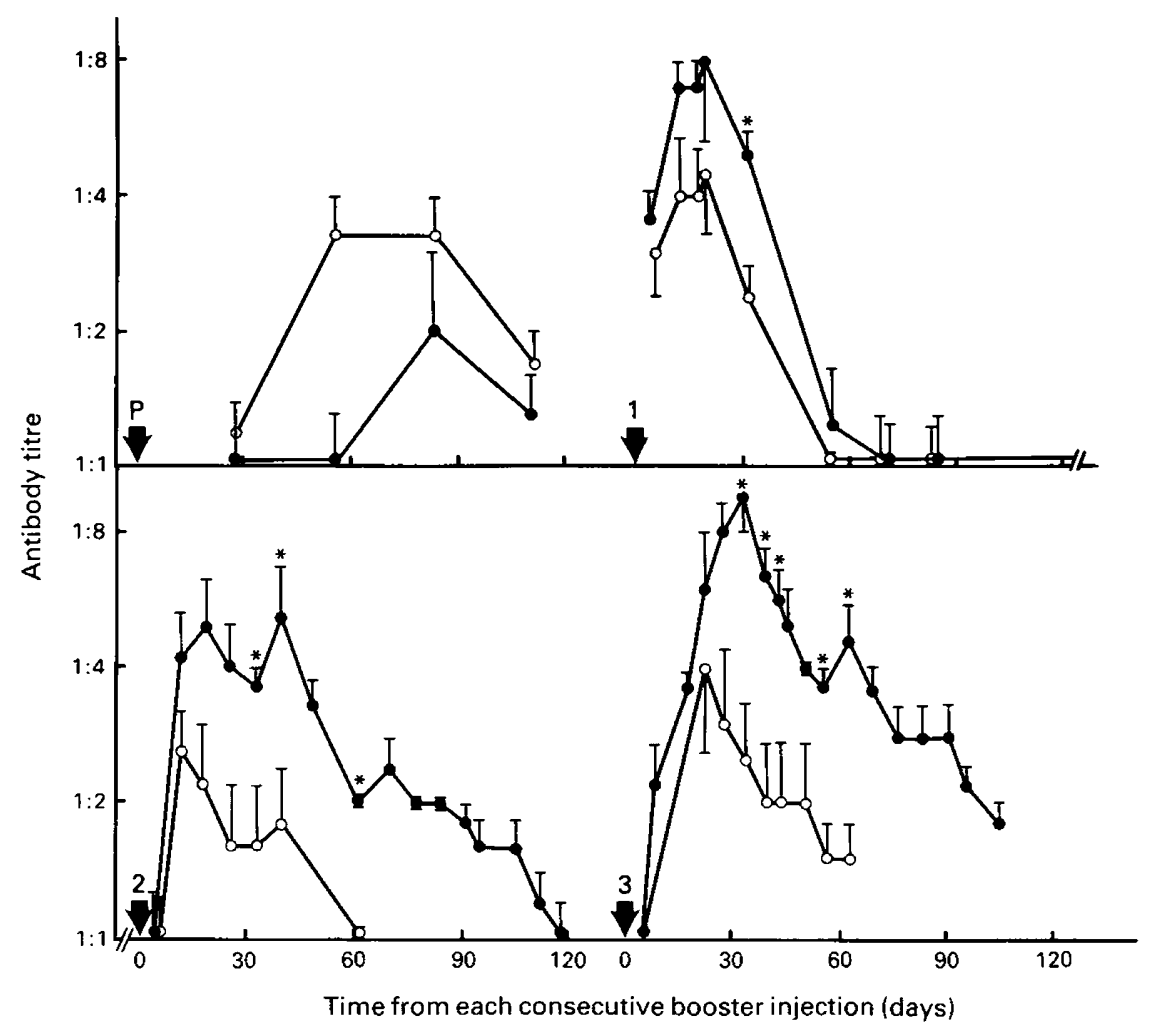

Fig. 2. Antibody titres (mean \pm s.e.m.) in heifers immunized against $0.4 \mathrm{mg}$ (Group B; $O$ ) or $4.0 \mathrm{mg}$ (Group D; - ) antigen in non-ulcerative Freund's adjuvant plus $C$. parvum and $B$. pertussis. Animals were injected 4 times at 4-month intervals (arrows). $\mathrm{P}=$ priming immunization; $1,2,3=$ consecutive booster injections. Note: time scale runs consecutively. ${ }^{*}$ Group $D$ differs from Group B, $P<0 \cdot 05$.

The antisera from Group D (4.0 mg antigen) animals cross-reacted strongly with ovine follicular fluid and serum, but weakly with bovine and porcine follicular fluids and bovine serum in the diffusion system used. No cross-reaction was detected with horse or human follicular fluids, BSA or any of the hormones tested. Immunoblotting techniques indicated that the antigen was a complex mixture of proteins of differing molecular weights, and that the heifers of Groups B and D responded to a large number of these component proteins (R. L. Spooner, R. A. Oliver, C. A. Price \& R. Webb, unpublished observations).

\section{Ovarian response}

Treatment with antigen in adjuvant without $C$. parvum had no effect on number of follicles or ovulations. The effect of treatment with $C$. parvum depended upon the amount of antigen given. One heifer in Group B ( $0.4 \mathrm{mg}$ protein) showed a double ovulation after the second booster injection. In contrast, among the 5 animals given $4.0 \mathrm{mg}$ (Group D) two showed double ovulations and one showed a triple ovulation at the first oestrus after the 2 nd booster injection (Table 2 ). The probability of observing 3 out of 5 animals with double ovulations (assuming a twinning rate as high as $8 \%$ ) is less than 0.005 . 
Table 2. Number of corpora lutea observed $(0=$ anovulation) in successive oestrous cycles for Groups B and D following second and third booster injections

\begin{tabular}{ccll}
\hline Group & $\begin{array}{c}\text { Animal } \\
\text { no. }\end{array}$ & $\begin{array}{c}\text { After second } \\
\text { booster }\end{array}$ & $\begin{array}{c}\text { After third } \\
\text { booster }\end{array}$ \\
\hline B & 1 & 1,1 & $0,1,1$ \\
& 2 & 1,1 & - $^{*}$ \\
& 3 & $-\dagger, 1,2$ & 1,1 \\
& 4 & 1,1 & 1,1 \\
D & 5 & $-\dagger, 1,1$ & $1,1,1$ \\
& 6 & $-\dagger, 3,1,1$ & $1,0,2,0,1$ \\
& 7 & $2,1,1$ & $0,1,1$ \\
& 8 & $-\dagger, 2,1,1$ & $1,1,1,1$ \\
& 9 & $1,1,1$ & $1,1,1$ \\
& 10 & $1,1,1$ & $1,1,1,1$ \\
\hline
\end{tabular}

*Heifer 2 was destroyed shortly before the third booster was due to be given.

†Missed observations, when oestrus occurred within 10 days of the second booster injection.

After the 3rd booster injection, one double ovulation was seen in a heifer from Group D, although three immunized animals showed short periods of anovulation (Table 2). In the 49 observations made on the control heifers, only one double ovulation was observed.

There were no differences between the number of large follicles observed in control and immunized heifers before the 3rd booster injection (data not shown). After the 3rd booster injection, however, the heifers in Group $D$ had more large follicles than did the control heifers $(1.2 \pm 0.2$ in Group D, $0.6 \pm 0.2$ large follicles per heifer in controls; $P<0.05)$, and those in Group B $(0 \cdot 7 \pm 0 \cdot 2$ large follicles per heifer). Similarly, for cycle length, Group D heifers demonstrated a significant difference from the control heifers for the cycles shown in Table 2 following the 3rd booster injection (19.1 \pm 0.3 vs $20 \cdot 0 \pm 0.3$ days for Group $D$ and controls, respectively; $P<0.05)$; anovulatory cycles were not included in this analysis.

There was no detectable correlation between ovulation rate and antibody titre at oestrus in any heifers from Groups B or D (data not shown). There appeared to be no correlation between the ovulatory response and the day of the oestrous cycle on which the heifers were immunized; however, the heifers in Group D which showed multiple ovulations after the 2 nd booster injection were all immunized on Days $14 / 15$ of the cycle, and the heifers with single ovulations were immunized between Days 6 and 9.

\section{Endocrine response}

There were no statistical differences in mean LH concentrations between Group B or Group D heifers and the control heifers after the 2 nd or 3 rd booster injections (data not shown). There was a trend for $\mathrm{LH}$ concentrations in the treatment groups to rise immediately after the 2 nd booster injection, but at this time 4 of the 5 animals in both treatment groups were in the follicular phase of the oestrous cycle, whereas there was only one follicular-phase control heifer.

At 5 weeks after the 2 nd booster injection, the mean FSH concentrations in Group B heifers were significantly higher than those of the control heifers, but not those of Group D heifers (Table 3). This effect was transient, and was probably not caused by an effect of the stage of the oestrous cycle as no differences were found in mean FSH concentrations between the luteal and follicular 
Table 3. Geometric FSH concentrations $( \pm$ s.e.m. $) \dagger$ in Groups $\mathbf{B}$ and $\mathbf{D}$ and control heifers after the second booster injection

\begin{tabular}{cccr}
\hline \multirow{3}{*}{$\begin{array}{c}\text { Time from } \\
\text { booster } \\
\text { injection }\end{array}$} & \multicolumn{3}{c}{ FSH (ng/ml) } \\
\cline { 2 - 4 } (weeks) & Group B & Group D & \multicolumn{1}{c}{ Control } \\
\hline 0 & $26 \cdot 8 \pm 8 \cdot 5$ & $14 \cdot 3 \pm 4 \cdot 5$ & $18 \cdot 3 \pm 5 \cdot 8$ \\
1 & $38 \cdot 0 \pm 12 \cdot 0$ & $44 \cdot 8 \pm 16 \cdot 7$ & $33 \cdot 1 \pm 14 \cdot 3$ \\
2 & $35 \cdot 2 \pm 10 \cdot 4$ & $33 \cdot 9 \pm 10 \cdot 9$ & $19 \cdot 1 \pm 8 \cdot 2$ \\
3 & $22 \cdot 1 \pm 7 \cdot 0$ & $32 \cdot 5 \pm 10 \cdot 3$ & $15 \cdot 3 \pm 4 \cdot 8$ \\
4 & $37 \cdot 8 \pm 12 \cdot 0$ & $13 \cdot 8 \pm 4 \cdot 3$ & $20 \cdot 4 \pm 6 \cdot 4$ \\
5 & $39 \cdot 8 \pm 12 \cdot 6^{*}$ & $18 \cdot 7 \pm 5 \cdot 9$ & $9 \cdot 0 \pm 2 \cdot 8$ \\
6 & $20 \cdot 8 \pm 6 \cdot 6$ & $18 \cdot 0 \pm 5 \cdot 7$ & $20 \cdot 1 \pm 6 \cdot 3$ \\
\hline
\end{tabular}

*Significantly higher than value in control group $(P<0 \cdot 05)$.

† Mean concentrations obtained from 15 samples weekly for

Groups B and D, and 27 samples weekly for the control group.

phases of the cycle in cattle of a similar age and breed (Price et al., 1987). There were no such differences between Group D and control animals.

Throughout this experiment, there were no differences between the mean progesterone concentrations of the control heifers and those of the heifers of either of the immunized groups $(P>0.05)$.

\section{Discussion}

This study demonstrates that active immunization of heifers against partly purified ovine follicular fluid can increase ovulation rate and the number of large ovarian follicles in cattle. The absence of superovulation or prolonged anoestrus in this study suggests that this technique may be more suitable for the induction of twinning in cattle than is active immunization against gonadal steroids. An increase in the number of large follicles has also been reported in inhibin-immunized sheep (Cummins et al., 1986). The reason that these follicles did not ovulate is not clear; the length of the oestrous cycle in the immunized heifers, although significantly lower than in the control heifers, was still within the expected range for this species (Hafez \& Sugie, 1963). The mechanisms by which corpora lutea and large follicle numbers can be increased by immunization against inhibin are not known, largely because the actions of inhibin itself have yet to be clarified.

If inhibin affects FSH secretion directly, it must reach the hypothalamus/pituitary gland via the peripheral circulation; immunization against inhibin would be expected to neutralize this circulating activity and hence increase FSH secretion and ovulation rate. Inhibin activity in the peripheral and ovarian blood of the large domestic species has only recently been described (Tsonis et al., 1986), although the lymphatic system may also be important for inhibin transportation (Findlay et al., 1986). The lack of a significant effect of the treatment on FSH concentrations in Group D heifers does not appear to support this hypothesis. The sheep studies previouslyseported (Henderson et al., 1984; O'Shea et al., 1984) have also indicated that active immunization against inhibin does not affect gonadotrophin secretion. Cummins et al. (1986) pointed out that differences in FSH secretion after immunization of ewes could be observed in an homologous RIA, but not in a heterologous assay. This may reflect differences in the molecular species of FSH secreted, as has been reported for the rat (Foulds \& Robertson, 1983; Chappel \& Ramaley, 1985), hamster (Chappel, 1981) and monkey (Chappel et al., 1984). The modulation of such forms of FSH in cattle and sheep may provide a further role for inhibin, and for other mechanisms of controlling differential LH and FSH secretion. However, a direct effect of these immunizations on gonadotrophin 
secretion cannot be excluded until more detailed examinations of pulsatile gonadotrophin secretion have been conducted.

The antibodies in the present study may have increased the number of active follicles in the ovaries by preventing some follicles from becoming atretic. Follicular fluid preparations have been reported to cause granulosa cell degeneration and to decrease aromatase enzyme activity in the immature rat and mature pig ovary (diZerega et al., 1983; Chari et al., 1985), both indicators of follicular atresia.

Clarification of the effects of immunization against inhibin and the precise physiology of inhibin should be aided by the availability of pure preparations of the hormone. Recent reports have revealed that the $\beta$-subunits of the two inhibin molecules present in follicular fluid (see Ling et al., 1985) can form dimers to produce an FSH-releasing protein of molecular weight 24000-28 000 (Ling et al., 1986; Vale et al., 1986). It is possible that antibodies have been raised to both FSHsuppressing and FSH-releasing proteins in the present study, particularly since the partly purified preparation contained a large number of proteins. The resultant antagonistic effects of these different antibodies may obscure changes in FSH secretion and ovarian activity, making it difficult to determine the mechanism by which the increased ovulation rate was achieved.

There was a marked difference in the efficacy of the adjuvants employed in the present study, which contrasts with our previous report of active immunization against a steroid conjugate (Price et al., 1987). Animals immunized without C. parvum did not produce any detectable antibodies, whereas those immunized with $C$. parvum exhibited high antibody titres without the formation of necrotic lesions usually associated with the use of Mycobacterium tuberculosis. It is suggested that non-ulcerative Freund's adjuvant with $C$. parvum should be used in cattle when high titres are desired from dilute or complex protein antigens.

In summary, these results show that a controlled increase in ovarian activity and ovulation rate can be achieved in cattle by actively immunizing against an inhibin-rich fraction of follicular fluid from sheep. This technique requires further development; we are currently investigating the endocrine effects of immunizing cattle against inhibin preparations from a wider range of species.

We thank the staff of the Dryden Laboratory, Roslin, for husbandry of cattle, recording of oestrus, and assistance in surgery; Dr S. S. Lynch, Birmingham and Midland Hospital for Women, and Dr R. B. Staigmiller and Dr D. J. Bolt, U.S. Department of Agriculture, for radioimmunoassay reagents; Dr M. A. Driancourt, I.N.R.A., Nouzilly, and Professor A. A. Templeton, Department of Obstetrics and Gynaecology, University of Aberdeen, for gifts of equine and human follicular fluid, respectively; Mrs N. B. Sharp for assistance with the progesterone assays and Mrs J. Cherrie for typing the manuscript. C.A.P. was in receipt of an AFRC postgraduate studentship. This work was funded in part by a grant from the CEC (No. 3710).

\section{References}

Bradford, G.E. (1985) Selection for litter size. In Genetics of Reproduction in Sheep, pp. 3-18. Eds R. B. Land \& D. W. Robinson. Butterworths, London.

Chappel, S.C. (1981) The presence of two species of follicle-stimulating hormone within hamster anterior pituitary glands as disclosed by concanavalin A chromatography. Endocrinology 109, 935-942.

Chappel, S.C. \& Ramaley, J.A. (1985) Changes in the isoelectric focusing profile of pituitary folliclestimulating hormone in the developing male rat. Biol. Reprod. 32, 567-573.

Chappel, S.C. \& Selkar, F. (1979) Relationship between the secretion of FSH during the periovulatory period and ovulation during the next cycle. Biol. Reprod. 21, $347-352$

Chappel, S.C., Bethea, C.L. \& Spies, H.G. (1984) Existence of multiple forms of follicle-stimulating hormone within the anterior pituitaries of cynomolgus monkeys. Endocrinology 115, 452-461.

Chari, S., Daume, E., Sturm, G., Vaupel, H. \& Schuler, 1. (1985) Regulators of steroid secretion and inhibin activity in human ovarian follicular fluid. Molec. cell. Endocr. 41, 137-145.

Cummins, L.J. (1983) Ovarian function in the Booroola 
Merino: the role of ovarian inhibiting factors in the regulation of ovulation rate. Ph.D. thesis, University of New England.

Cummins, L.J., O'Shea, T., Al-Obaidi, S.A.R., Bindon, B.M. \& Findlay, J.K. (1986) Increase in ovulation rate after immunization of Merino ewes with a fraction of bovine follicular fluid containing inhibin activity. J. Reprod. Fert. 77, 365-372.

diZerega, G.S., Marrs, R.P., Campeau, J.D. \& Kling, O.R. (1983) Human granulosa cell secretion of protein(s) which suppress follicular response to gonadotropins. J. clin. Endocr. Metab. 56, 147-155.

Findlay, J.K., Tsonis, C.G., Staples, L.D. \& Cahill, R.N.P. (1986) Inhibin secretion by the sheep ovary. $J$. Reprod. Fert. 76, 751-761.

Foulds, L.M. \& Robertson, D.M. (1983) Electrofocusing fractionation and characterization of pituitary follicle-stimulating hormone from male and female rats. Molec. cell. Endocr. 31, 117-130.

Hafez, E.S.E. \& Sugie, T. (1963) Behavioural oestrus and ovulatory cycle in beef cattle with a note on the clay model technique. Acta zool., Stockh. 44, 57-71.

Henderson, K.M., Franchimont, P., Lecomte-Yerna, M.J., Hudson, N. \& Ball, K. (1984) Increase in ovulation rate after active immunization of sheep with inhibin partially purified from bovine follicular fluid. J. Endocr. 102, 305-309.

Ireland, J.J., Curato, A.D. \& Wilson, J. (1983) Effect of charcoal-treated bovine follicular fluid on secretion of LH and FSH in ovariectomised heifers. J. Anim. Sci. 57, 1512-1516.

Jansen, E.H.J.M., Steenbergen, J., de Jong, F.H. \& van der Molen, H.J. (1981) The use of affinity matrices in the purification of inhibin from bovine follicular fluid. Molec. cell. Endocr. 21, 109-117.

Ling, N., Ying, S.Y., Ueno, N., Esch, F., Denoroy, L. \& Guillemin, R. (1985) Isolation and partial characterization of a $\mathrm{Mr} 32,000$ protein with inhibin activity from porcine follicular fluid. Proc. natn. Acad. Sci. U.S.A. 82, 7217-7221.

Ling, N., Ying, S.Y., Ueno, N., Shimasaki, S., Esch, F., Hotta, M. \& Guillemin, R. (1986) Pituitary FSH is released by a heterodimer of the $\beta$-subunits from the two forms of inhibin. Nature, London. 321, 779-782.

Maijala, K. \& Syvajarvi, J. (1977) On the possibility of developing multiparous cattle by selection. $Z$. Tierzücht. ZüchtBiol. 94, 136-150.

Martin, T.E., Henricks, D.M., Hill, J.R. \& Rawlings, N.C. (1978) Active immunization of the cow against oestradiol-17ß. J. Reprod. Fert. 53, 173-178.

McNeilly, A.S. (1984) Changes in FSH and the pulsatile secretion of LH during the delay in oestrus induced by treatment of ewes with bovine follicular fluid. $J$. Reprod. Fert. 72, 165-172.

Miller, K.F., Critser, J.K., Rowe, R.F. \& Ginther, O.J. (1979) Ovarian effects of bovine follicular fluid treatment in sheep and cattle. Biol. Reprod. 21, 537-544.
O'Shea, T., Al-Obaidi, S.A.R., Hillard, M.A., Bindon, B.M., Cummins, L.J. \& Findlay, J.K. (1984) Increased ovulation rate in Merino ewes and advancement of puberty in Merino lambs immunized with a preparation enriched in inhibin. In Reproduction in Sheep, pp. 335-337. Eds D. R. Lindsay \& D. T. Pearce. Australian Academy of Science, Canberra.

Ouchterlony, O. \& Nilsson, L.A. (1978) Immunodiffusion and immunoelectrophoresis. In Handbook of Experimental Immunology, pp. 19.1-19.44. Ed D. M. Weir. Blackwell Scientific Publications, Oxford.

Price, C.A., Morris, B.A. \& Webb, R. (1987) Reproductive and endocrine effects of active immunization against a testosterone conjugate in the heifer. $J$. Reprod. Fert. 81, 149-160.

Quirk, S.M. \& Fortune, J.E. (1986) Plasma concentrations of gonadotrophins, preovulatory follicular development and luteal function associated with bovine follicular fluid-induced delay of oestrus in heifers. J. Reprod. Fert. 76, 609-621.

Rutledge, J.J. (1975) Twinning in cattle. J. Anim. Sci. 40, $803-815$.

Scaramuzzi, R.J. \& Hoskinson, R.M. (1984) Active immunization against steroid hormones for increasing fecundity. In Immunological Aspects of Reproduction in Mammals, pp. 445 474. Ed D. B. Crighton. Butterworths, London.

Tsonis, C.G., McNeilly, A.S. \& Baird, D.T. (1986) Measurement of exogenous and endogenous inhibin in sheep serum using a new and extremely sensitive bioassay for inhibin based on inhibition of ovine pituitary FSH secretion in vitro. J. Endocr. 110, 341-352.

Vale, W., Rivier, J., Vaughan, J., McClintock, R., Corrigan, A., Woo, W., Karr, D. \& Spiess, J. (1986) Purification and characterization of an FSH releasing protein from porcine ovarian follicular fluid. Nature, Lond. 321, 776-779.

Webb, R. (1987) Increasing ovulation rate and lambing rate in sheep by treatment with a steroid enzyme inhibitor. J. Reprod. Fert. 79, 231-240.

Webb, R., Land, R.B., Pathiraja, N. \& Morris, B.A. (1984) Passive immunization against steroid hormones in the female. In Immunological Aspects of Reproduction in Mammals, pp. 475-499. Ed. D. B. Crighton. Butterworths, London.

Welschen, R., Hermans, W.P., Dullaart, J. \& de Jong, F.H. (1977) Effects of an inhibin-like factor present in bovine and porcine follicular fluid on gonadotrophin levels in ovariectomised rats. J. Reprod. Fert. 50, 129-131.

Wise, T.H. \& Schanbacher, B.D. (1983) Reproductive effects of immunizing heifers against androstenedione and oestradiol-17ß. J. Reprod. Fert. 69, $605-612$. 